\title{
Using WordPress-Portfolios for Teaching and Learning Mathematics in Engineering Studies
}

\author{
Using WordPress for Teaching and Learning Mathematic
}

\author{
Judit Taberna Torres \\ Dept. d' Expressió Gràfica \\ Arquitectónica I \\ Universitat Politècnica de Catalunya \\ Barcelona, Spain \\ Judit.tabema@gmail.com
}

\author{
Santiago Domínguez-García \\ Dept. de Pedagogia \\ Universitat Rovira I Virgili \\ Tarragona, Spain \\ soyelsanti31@gmail.com
}

\author{
M. Isabel García-Planas \\ Dept. Matemàtica Aplicada I \\ Universitat Politècnica de catalunya \\ Barcelona, Spain \\ maria.isabel.garcia@upc.edu
}

\begin{abstract}
In recent years is becoming habitual use of the electronic portfolio for learning and assessment of students. This is due to the need for teachers empower students through reflection on their own learning processes. Recently, we have worked with Mahara, Exabis, Google Sites and WordPress software, in order to compare them and see which makes it easier the work of the student, thereby facilitating the generation and use of e-portfolio by students. In this paper, the recent experience in the use of it for undergraduate engineering students.
\end{abstract}

\section{Keywords- WordPress, Linear Algebra, Portfolio}

\section{INTRODUCTION}

The French word "portefeuille" deriving from the Latin verb portare that means to carry, and the Latin noun foglio, that means sheets, it has been taken to describe a "portfolio" that is defined as a collection of works or documents that are representative of skills and accomplishments of a person.

When it comes to university teaching, the word comes from "portfolio assessment" or "portfolio process", so it has the sense of "assessment folder" or a broader form of "learning portfolio". In the case where this activity takes place on a digital platform called an e-portfolio. More specifically in our particular context, the portfolio is a method of teaching, learning and assessment, it is the contribution of different types of productions by students through which they can be judge their abilities in the context of a discipline or field of study.

There are many available sites for building an e-portfolio. However, it is very important to know the pros and cons when choosing an e-portfolio provider site. That is because the Institute of Educational Sciences of the Catalonian Polytechnic University promotes a research group that analyzes the different platforms in order to find the most suitable for use in the various subjects taught

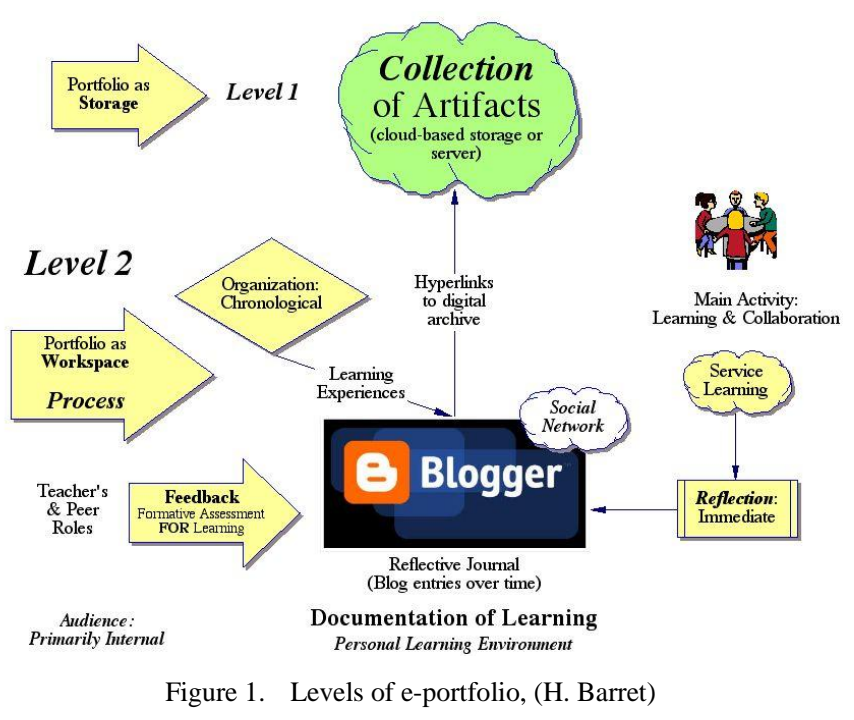

As is well known a blog is an online journal encouraging communicate ideas, and personal entries are usually, exhibited in reverse chronological order.

Blogs provide a good tool for building learning journals, as you can read in [1], where it is suggested that "e-Journals help create e-portfolios in a more authentic and relevant to student life form". Focusses on reflection and research.

The Fig. 1 and Fig. 3 created by H. Barrett [2] and S. Leslie [3] graphically displayed using blogs to create eportfolios.

In recent years many authors working in the introduction of the e-portfolio at the higher education, as we can see in [4], [5], [6], [7], [8], [9], [10], [11], [12] and [13] for example. 


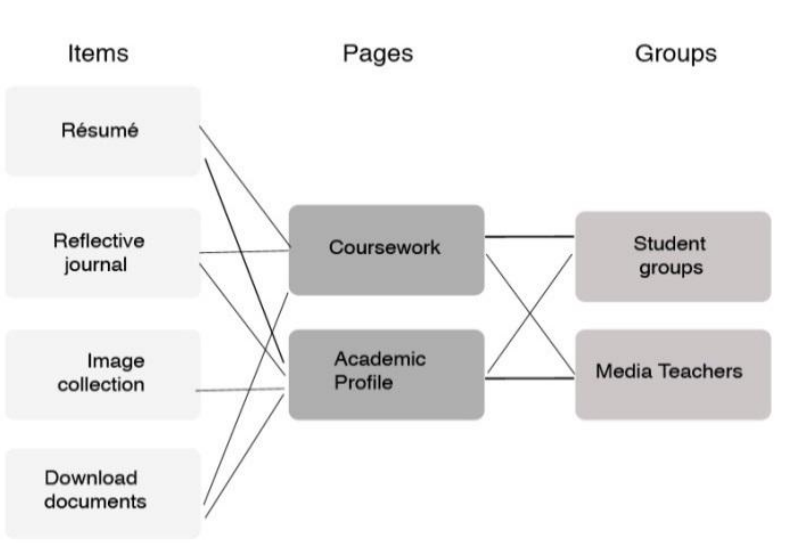

Figure 2. Organizing a portfolio: Schema

The main goal of this work is to analyze if the use of the eportfolio increases the success of students of mathematics in engineering school.

\section{TYPES AND CONTENTS OF PORTFOLIOS}

There are many types of e-portfolios, with different uses that sometimes, cause confusion among teachers, in particular about the practical issues surrounding the storage, ownership, etc.

The three main types of e-portfolios are, learning eportfolios, display e-portfolios, and assessment e-portfolios

a) Assessment E-Portfolio:

It allows assessing the achievement of specific criteria to obtain a degree or work.

b) Learning E-Portfolio:

Allows providing information on learning objectives incorporating both self-reflection and the student and the teacher

c) Display E-Portfolio or Demonstration of best practices eportfolio. Allows submit information to specific audiences or achievements.

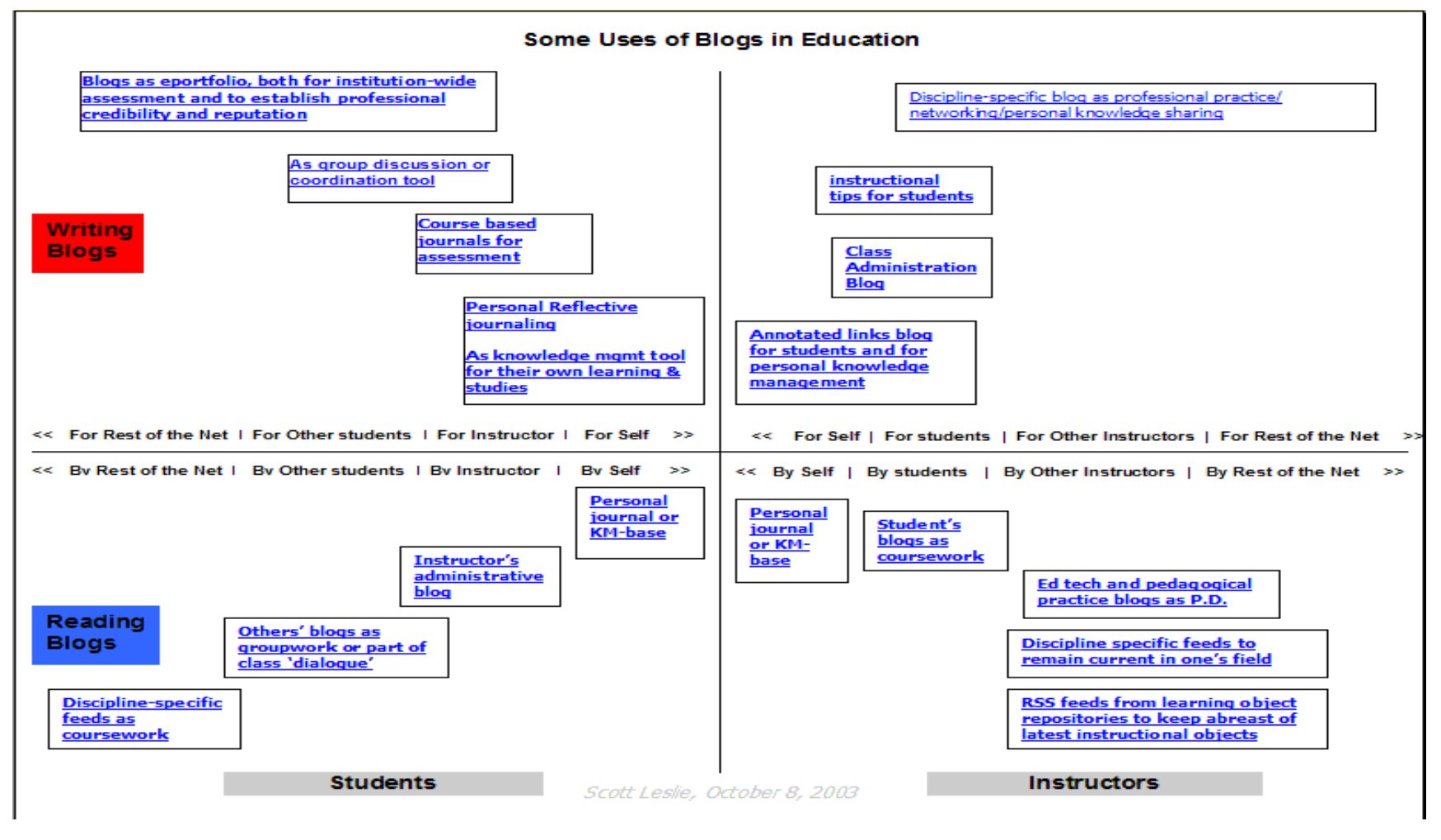

Figure 3. Leslie Matrix (2003)

The purpose for which the e-portfolio is created determines what happens in it.

In Fig. 2, we show a schema, relating the artifacts that are part of the portfolio, with pages that integrate it and the groups that should compose it, in order to clarify its structure.

Finally and after observing that the different uses of eportfolio are not exclusive, and all of them, can be used simultaneously, we believe that the most appropriate is to use the "integral e-portfolio", that is to say an e-portfolio that integrates all the different uses. With this kind of e-portfolio, cooperative and collaborative learnings is stimulated, these types of learning are very significant for engineering studies (see [14]).

\section{E-PORTFOLIO PLATFORMS}

Now, we are going to talk about some of the tools used for creating and managing electronic portfolios used in the course 
of linear algebra corresponding to engineering studies in the ETSEIB at UPC. Before we begin we will note that when a student creates a portfolio it is important to remember at any time that the tool is only a means and should never be considered as the ultimate goal.

Several authors as for example Diana Bri, Miguel García, Hugo Colls, Jaime Lloret in [15]), examine educational portfolio platforms in order to facilitate the decision about platform on which to choose.

In 2012 we started a research about the e-portfolios platforms and how to implement these with the software of the university. The UPC works with an adapted version of Moodle platform, with the name of Atenea, for all the communication and academic works of the students.

Atenea is a virtual environment where is hosted and manages the virtual environment the Universitat Politècnica de Catalunya teaching. It has been designed with the aim to support the adaptation of the studies of the UPC to the guidelines of the European Higher Education. It is accessible through the website http://atenea.upc.edu.

We started working in Atenea Labs that is an independent work environment of the virtual campus Atenea (Fig. 4) and isolated from other information systems where expert groups perform tests and innovative initiatives without interfering with the normal operation of the virtual campus Atenea.

There are several online-platforms, which allow building a personal e-portfolio. The Institute of Educational Science of UPC (ICE) in 2013, propose us to start our research with Mahara, more specifically with Mahoodle. Nevertheless, we focus not only with this platform. Concretely, we decided to encourage our students to work with three different platforms (Mahoodle, Exabis and Google Sites).

In 2014, we analyze all these results and we realize that the students wanted a more flexible, free and open access platform. However, the most important premise for the professors was that it has to be related to the university.

For that reason in 2015 , we implemented a pilot case with the Wordpress platform but related to UPC, with the students of Algebra Linear course in the ETSEIB.

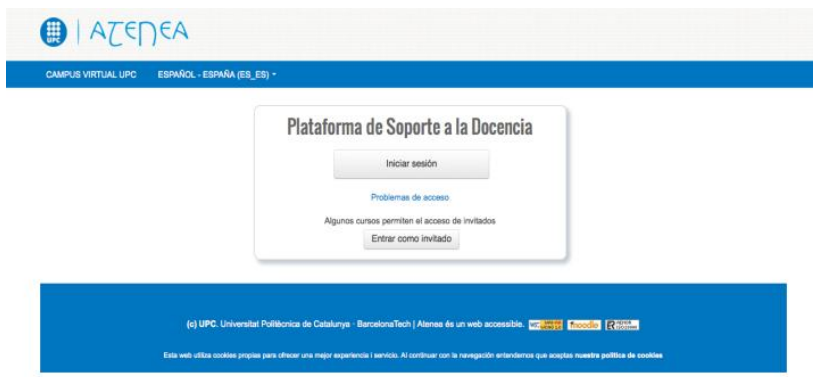

Figure 4. Virtual Campus UPC-Atenea

\section{A. WordPress}

WordPress (Fig. 5) is a free and open-source tool and a content management system. Features include a plugin architecture and a template system. The ICE, UPC created an institutional template for all the students as well as, five different models of graphic representation for the visualization of their portfolios.

They create all the URL of the portfolios of the students; also manage the limit storage size of each student site.

All student e-portfolios are hosted in this URL: HTTP: //portafoli.upc.edu/, and then UPC assigned a personal site with the student's name in the address. All the portfolios are open access, but only the students are the ones that can edit and erase the information of their own portfolio.

\section{B. Mahoodle}

Mahara (Fig. 6) a maori word meaning "think" or "thought" is an open source e-portfolio system and social networking web application. Mahara also traits a weblog, resume builder and social networking system, connecting users and creating online learner communities.

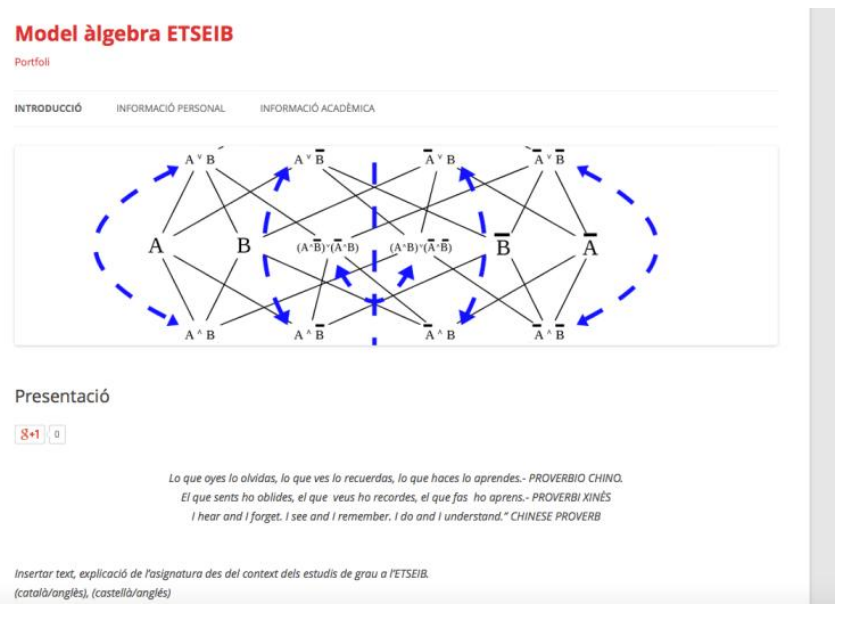

Figure 5. WordPress

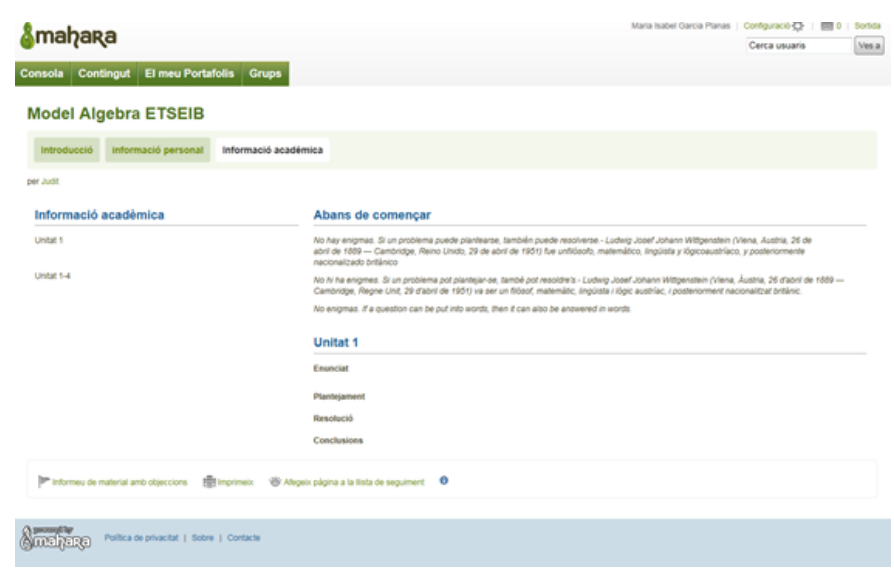

Figure 6. Mahara 
Moodle it is an open source e-learning platform, also known as a Learning Management System, or Virtual Learning Environment. Both systems have built-in support for each other in the form of single sign-on and transfer of content or export different types of objects from Moodle to Mahara (API Portfolio) and to import objects from Mahara to Moodle (API repository).

\section{Exabis}

Exabis (Fig. 7) is also an open source of e-Portfolio able to connect to Moodle by means of a plug. We are using the eportfolio 4.1 version for Moodle, "My Portfolio" in Exabis, let us users upload files. Several features can be considered relevant for e-portfolio-work with Exabis, in particular the publication of links within Moodle and the possibility of self-reflection, and documentation of student personal learningstyle by using private notes (with the option for publication within Moodle).

\section{Google Sites}

Google Sites (Fig. 10) is a free online application offered by the company Google. This application allows us to create a website in a simple editing a document. Both teachers and students can put in one place texts and images, as well as to include multiple documents. It also allows easy sharing personalized

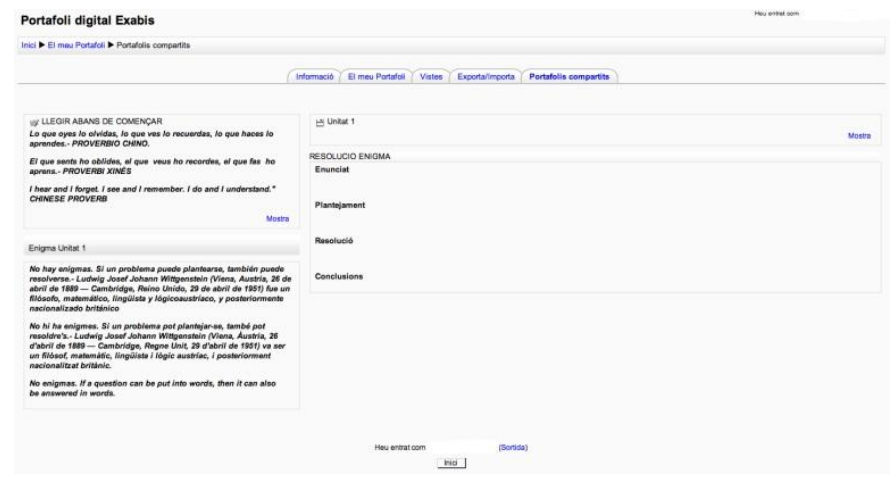

Figure 7. Exabis

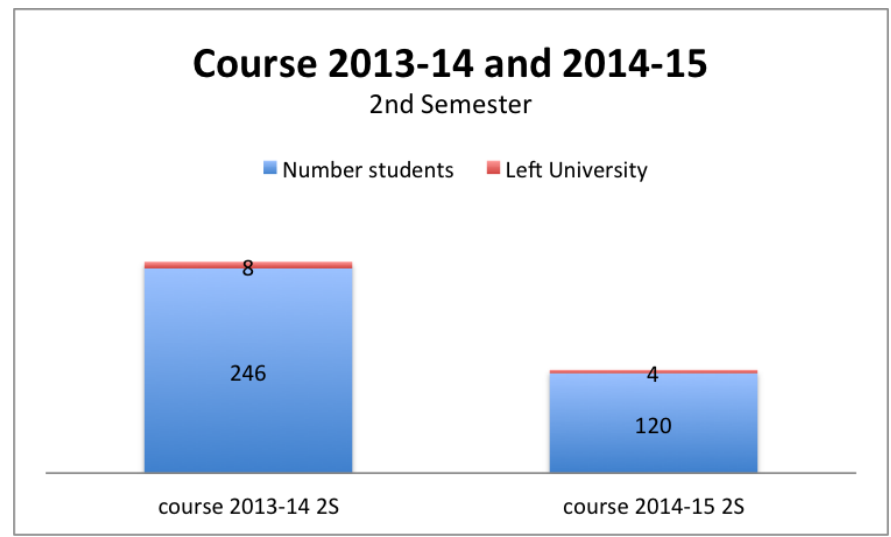

Figure 8. Comparing number of repeaters information across the network with a group of collaborators. However, one limitation of this application is the storage space.

\section{RESULTS}

Once finished the course, we compare the marks obtained by the students of this course and the previous course (control group). Concretely, the percentage of students who have passed the subject has been of $749 \%$ compared to the control group that was only $51 ' 2 \%$.

After implementing the e-portfolio we observe in Fig. 8 that to halve the number of students repeating the course in the second semester.

In the second semester the percentage of failures was $18,66 \%$ compared to the control group that was of $42^{\prime} 71 \%$ (see Fig. 9).

\section{CONCLUSIONS}

The students of a first course in linear algebra ETSEIBUPC (semester course) performed the experience. The number of students participating in the pilot were 680. Students were grouped in 10 groups, each supervised by a different teacher. Each student made his own e-portfolio, nevertheless the projects

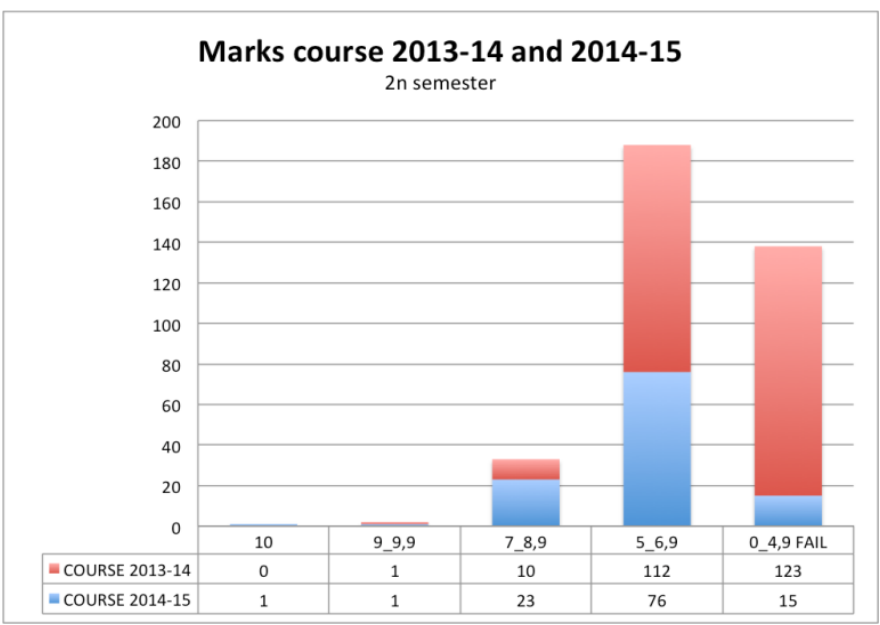

Figure 9. Comparing marks of repeaters

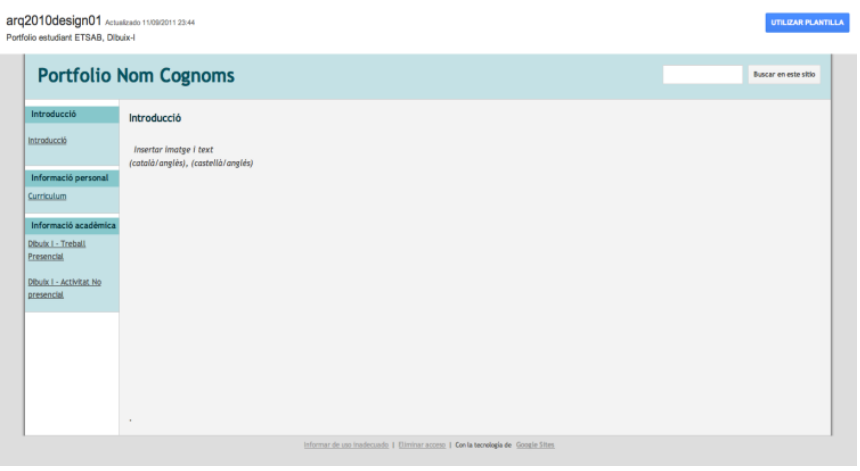

Figure 10. Google Sites 
were developed in subgroups of four students, thereby enhancing cooperative work.

During the first week of the course, Teachers explained that it is an e-portofolio and the projects that students had to perform both individually and collectively (see Fig.9). As well as the teachers showed a complete structured semester planning for weeks.

For the realization of these projects, the student has had progressively take into account each of the parts of the course syllabus.

The use of e-portfolios have demonstrated that the students improved learning concepts to be achieved and that had previously been defined. There has also been improvement in student autonomy in the resolution of work both individually and as a group.
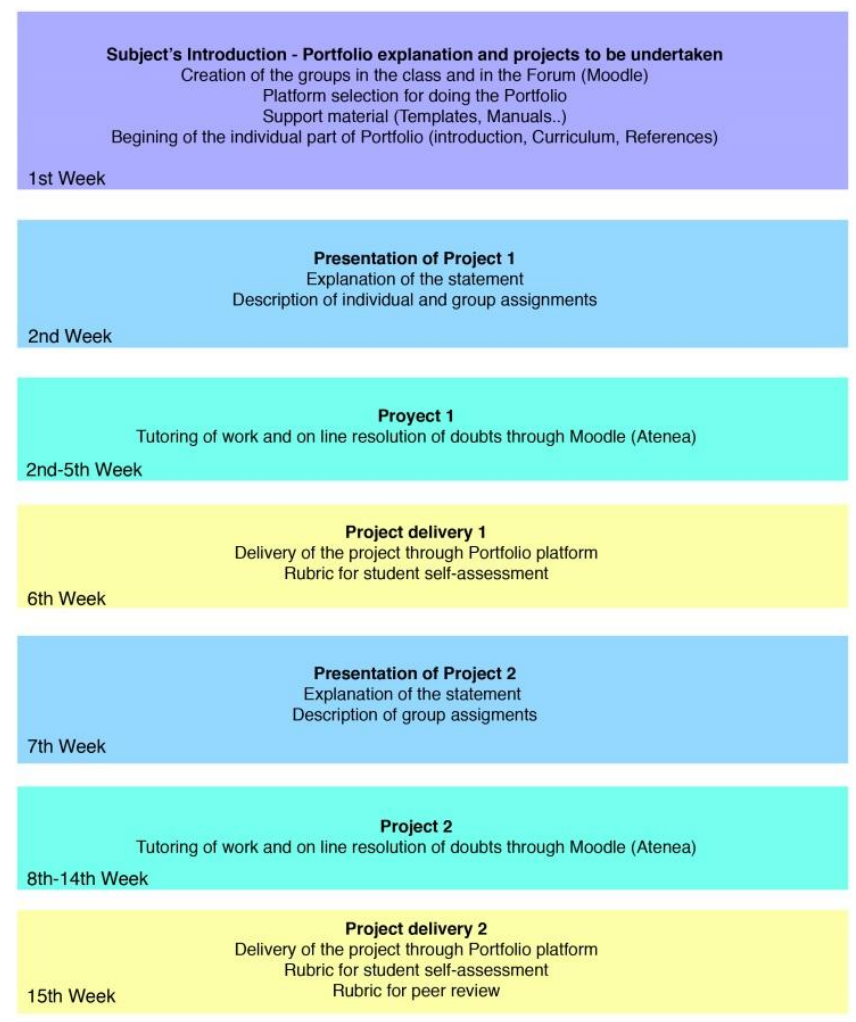

Figure 11. Subject Planning

\section{REFERENCES}

[1] M.A. Bairral, R.T. dos Santos, E-Portfolio Improving Learning in Mathematics Pre-Service Teacher. Digital Education Review, vol. 21. (2012), pp. 1-12.

[2] R. Barragán. El portafolio, metodología de evaluacil'on y aprendizaje de cara al nuevo espacio Europeo de Educación superior. Una experiencia práctica en la Universidad de Sevilla. Revista Latinoamericana de Tecnología Educativa, vol. 4 (1), (2005), pp. 121-139.

[3] H. Barrett, Create Your Own Electronic Portfolio (using off-the-shelf software). Learning and Leading with Technology, (2000).

[4] G.M. Brandes, N. Boskic, E-portfolios: From description to analysis\}. International. Review of Research in Open and Distance Learning, vol. 9, (2), (2008), pp. 1-17.

[5] S.C. Cismas, Effective Foreign Language Portfolios in Engineering Education. Wseas Transactions on Advances in Engineering Education vol. 6, (11), (2009), pp. 383-398.

[6] R. C. Costa, The use of the e-portfolios in the student's learning at the Federal e Institute of Education, Science and Technology of Maranhâo/Campus Codó. Seropédica, Rio de Janeiro, UFRRJ/PPGEA (Master Dissertation in Education). (2009).

[7] S. Domínguez-García, M.I. García-Planas, R. Palau, J. Taberna. Uso del e-portafolio en la formación: El e-portafolio integral. Revista del Congrés Internacional de Docència Universitària i Innovació (CIDUI), núm. 2 (2014).

[8] S. Jones, (2008). E-portfolios and how they can support Personalisation. Improving learning through technology. Becta UK (2008).

[9] A. Pitarch, A. Álvarez, J. Monferrer, El ePEL: la gestión del aprendizaje a lo largo de la vida. Portafolios electrónicos y Educación Superior en España. http://www.um.es/ead/Red_U/m3/. (2009).

[10] C. Mccowan, W. Harper, K. Hauville, (2005). \{ lit Student E-Portfolio: The Successful Implementation of an E-Portfolio across a Major Australian University\}. Australian Journal of Career Development. Vol. 14, (2), pp. 40-51.

[11] I. Asshaari, H. Othman, N. Razali, N.M. Tawil, F.H.M. Ariff, Comparison between Level of Students' Responses toward Cooperative Learning in Mathematics Engineering Courses at UKM. Wseas Transactions on Advances in Engineering Education, vol. 8, (2), (2011), pp. 53-61.

[12] D. Bri, M. García, H. Coll, J. LLoret, A Study of Virtual Learning Environments. Wseas Transactions on Advances in Engineering Education, vol. 6, (1), (2009), pp. 33-43.

[13] S. Leslie, (2003). "Matrix of some uses of blogs in education" EdTechPost, 9. http://www.edtechpost.ca/mt/archive/000393.html [Retrieved: Mai, 12, 2015]

[14] Crichton, S. and Kopp, G. (2008) "The Value of eJournals to Support ePortfolio Develonment for Assessment in Teacher Education." in Canadian Journal of Learning and Technology V34(3) Fall 2008

[15] H. Barrett, Interactive e-Portfolios with Google Apps, electronicportfolios.org. (retrieved in Mai, 15 2015). 